TITLE:

\title{
The development of a novel wound healing material, silk-elastin sponge(Abstract_要旨)
}

$\operatorname{AUTHOR}(\mathrm{S}):$

Kawabata, Shingo

\section{CITATION:}

Kawabata, Shingo. The development of a novel wound healing material, silk-elastin sponge. 京都大学, 2019, 博士(医学)

\section{ISSUE DATE:}

2019-07-23

URL:

https://doi.org/10.14989/doctor.r13266

\section{RIGHT:}

This is an Accepted Manuscript of an article published by Taylor \&

Francis in Journal of Biomaterials Science, Polymer Edition on 28 Sep. 2017, available online:

http://www.tandfonline.com/[DOI:10.1080/09205063.2017.1382829 ]. 


\begin{tabular}{|l|l|c|c|}
\hline 京都大学 & 博士（医 学 ） & 氏 名 & 川端 慎 吾 \\
\hline 論文題目 & $\begin{array}{l}\text { The development of a novel wound healing material, silk-elastin sponge } \\
\text { (新規創傷治㾑材料シルクエラスチンの開発) }\end{array}$
\end{tabular}

(論文内容の要旨)

\section{【目的】}

創傷治癒を促進するためには、創傷面の環境を整えること(wound bed preparation) に加えて、創傷の乾燥を防ぎ、創傷治瘉に不可欠な細胞やサイト カインなどを含んだ滲出液を適切に維持された状態を創り出し治療する moist wound healing が重要視されている。シルクエラスチンはシルクフィブロイン 由来配列（G A G A G S 配列）とエラスチン由来配列（GＶＧＶＰ配列）との 繰り返し配列からなる人工タンパク質である。シルクエラスチン水溶液は、低 温ではシルクフィブロイン配列の水素結合により凝集しているが、温度上昇に 上り水素結合が弱まり、親水性の高いエラスチン配列が水分を構造内部に抱き 込んだまま膨潤することによりゲル化をする。これまでにシルクエラスチンは 水溶液（SEA）を患部に投与寸る創傷治瘉材として、肉芽組織形成促進作用およ び上皮化促進作用を有することを報告してきた。しかし、患部での液ダレや広 範囲での使用等の臨床上の課題があった。そこで、このシルクエラスチンを臨 床現場のニーズに応えるべく、ユーザビリティや保存安定性の観点からシルク エラスチンスポンジ（SEP）を作製した。今回、密度や厚みを変えた SEP につい て、創傷治癒効果を SEA と比較検証した。

\section{【方法】}

<SEP の作製＞密度 $\left(12.5-100 \mathrm{mg} / \mathrm{cm}^{3}\right)$ ならびに厚み $(1.25-5 \mathrm{~mm})$ を変えた SEP を合計 6 群について、凍結乾燥にて作製した。<創傷治瘉効果評価＞健常モル モットの背部に直径 $8 \mathrm{~mm}$ の全層皮膚欠損創を作製し、SEA もしくは SEP を投与 乙（n=4-8）、投与後 5 日目に創傷部の病理標本を作製し、組織学的評価を行っ た。また、糖尿病マウスの第 3 転子部にIV 度裖瘡作製後 5 日目に壊死組織除去 を行い、同様に検体を投与し、14 日目に組織学的評価を行った。<SEP 群のゲ ル内サイトカイン量測定＞健常モルモット背部全層皮膚欠損創に SEP 投与した 後、24 時間目に創傷部でゲル化した SEPを摘出してゲル内に含まれているサイ トカイン量（bFGF、TNF $\alpha$ および IL-1 $\beta$ ) を ELISA キットにて測定した（n=3）。 【結果】

健常モルモットの背部を用いた全層皮膚欠損創モデル実験より、SEP の密度 や厚みに応じて、創傷治癒効果（肉芽組織形成能）は可変したが、SEA と同レ ベルの効果を示す SEP（密度 $25 \mathrm{mg} / \mathrm{cm}^{3}$ 、厚み $5 \mathrm{~mm}$ ） が得られた。また、糖尿病 マウスの第 3 転子部を用いた IV 度裖瘡モデル実験からも、SEP は SEA と同レベ ルの創傷治癒効果を示した。一方、SEP から得られたゲル化物内には、未投与 群と比較して 2-20 倍量のサイトカインが含まれていた。

\section{【考察】}

SEP は創傷面の滲出液を吸収・ゲル化することにより、SEA と同様に moist wound healing が可能であり、ゲル内に渗出液由来のサイトカインを含有するため、 安定した創傷治癒効果が発揮できる。また、シルクエラスチン自体が有する線 維芽細胞に対する細胞遊走能やシルクェラスチンゲルとしての細胞足場機能も 維持されるため、SEP はSEA と同等の創傷治瘉効果を持つ。さらに、SEP は SEA と比較して確実に創傷面に留置できるため、臨床での使用において有利に㗢く ものと考える。
【結論】

このように SEP は、これまでの創傷治療材料と異なる特性を有していること から、創傷に対する治療方法の選択の幅を広げ、治療成績向上に貢献できると 考える。また、2018 年 2 月から下腿難治性潰瘍に対してシルクエラスチンスポ ンジの医師主導治験を実施しており、従来治療困難であった対象疾患に対する 適応拡大の可能性も示唆寸るものである。

（論文審査の結果の要旨）

【目的】シルクエラスチン水溶液（SEA）を創部に投与すれば体温でゲル化し、創傷治 癒効果を有することを明らかにしてきた。しかし、水溶液は創部周囲へ漏れや寸いなど 臨床応用面での課題があったため、シルクエラスチンをスポンジ形状（SEP）に加工し、 創傷治癒効果を SEA と比較検証した。

【方法】密度 : 12. 5 100 mg/cm 、厚み: 1. 25〜 $5 \mathrm{~mm}$ のSEP を作製し、ゲル化能、物理 的強度を調べた。また、健常モルモット背部の全層皮膚欠損モデルならびに糖尿病マウ スのIV度裖瘡モデルで、肉芽組織形成を評価した。健常モルモット背部の全層皮膚欠損 創でゲル化した SEP を摘出、ゲル内に含まれているサイトカイン量を測定した。

【結果・結論】ゲル化時間は密度や厚みによる違いはなかったが、物理的強度は密度に 応じて可変した。全層皮膚欠損創モデルでは、密度 $25 \mathrm{mg} / \mathrm{cm}^{3}$ 、厚み $5 \mathrm{~mm}$ ならびに密度 $12.5 \mathrm{mg} / \mathrm{cm}^{3}$ 、厚夕 $5 \mathrm{~mm}$ の SEP は、SEA と同レベルの肉芽組織形成を示した。また、IV 度裖瘡モデルでも、密度 $25 \mathrm{mg} / \mathrm{cm}^{3}$ 、厚み $5 \mathrm{~mm}$ の SEP は SEA と同レベルの肉芽組織形 成を示した。一方、SEPから得られたゲル化物内には、コントロール群と比較してbFGF が 3 倍量、 20 倍量の TNF $\alpha 、 3$ 倍量の IL-1 $\beta$ が含まれていた。SEP は水溶液と比へ臨床 使用しや寸く、難治性皮膚創傷に対寸る新たな治療材料として治療成績向上に貢献でき 万可能性が示された。

以上の研究はシルクエラスチンが創傷治癒を促進することを示し、今後の創傷治療の 進歩に寄与するところが多い。

したがって、本論文は博士（医 学）の学位論文として価値あるものと認める。

なお、本学位授与申請者は、平成 31 年 4 月 8 日実施の論文内容とそれに関連した 研究分野並びに学識確認のための試問を受け、合格と認められたものである。 